\begin{tabular}{|l|l|l||}
\hline \multicolumn{2}{|c|}{ PublisherInfo } \\
\hline \hline PublisherName & $:$ & BioMed Central \\
\hline \hline PublisherLocation & $:$ & London \\
\hline \hline PublisherImprintName & $:$ & BioMed Central \\
\hline \hline
\end{tabular}

\title{
Pseudomonas switch to resistance
}

\begin{tabular}{|l|l|l||}
\hline \multicolumn{2}{|c|}{ ArticleInfo } \\
\hline \hline ArticleID & $:$ & 4456 \\
\hline \hline ArticleDOI & $:$ & $10.1186 /$ gb-spotlight-20020422-01 \\
\hline \hline ArticleCitationID & $:$ & spotlight-20020422-01 \\
\hline \hline ArticleSequenceNumber & $:$ & 122 \\
\hline \hline ArticleCategory & $:$ & Research news \\
\hline ArticleFirstPage & $:$ & 1 \\
\hline \hline ArticleLastPage & $:$ & 2 \\
\hline \hline & & RegistrationDate : 2002-4-22 \\
\hline ArticleHistory & $:$ & OnlineDate \\
\hline \hline ArticleCopyright & $:$ & BioMed Central Ltd2002-4-22 \\
\hline \hline ArticleGrants & $:$ & \\
\hline \hline ArticleContext & $:$ & 130593311 \\
\hline \hline
\end{tabular}




\section{Tudor Toma}

Email: t.toma@ic.ac.uk

Pseudomonas aeruginosa grows as biofilms in the lungs of patients with cystic fibrosis (CF) but it remains unclear whether the bacteria persist because the biofilms are antibiotic-resistant or if resistant variants are selected by antimicrobial therapy itself. In the April 18 Nature, Eliana Drenkard and Frederick Ausubel of Harvard Medical School show that biofilm formation and antibiotic resistance in Pseudomonas are linked to phenotypic variation and are switched on together.

Drenkard \& Ausubel observed that antibiotic-resistant phenotypic variants of $P$. aeruginosa with enhanced ability to form biofilms arise at high frequency both in vitro and in the lungs of people with $\mathrm{CF}$. They also identified a regulatory protein (PvrR) that controls the conversion between antibioticresistant and antibiotic-susceptible forms (Nature 2002, 416:740-743).

"Drenkard and Ausubel have described a general mechanism - environment-driven phenotypic switching - that explains how antibiotic-resistant biofilm variants of $P$. aeruginosa arise," wrote George O'Toole of Dartmouth Medical School in the accompanying News and Views article.

"Compounds that affect PvrR function could have an important role in the treatment of CF infections", conclude Drenkard and Ausubel.

\section{References}

1. Drenkard E and Ausubel FM: Pseudomonas biofilm formation and antibiotic resistance are linked to phenotypic variation. Nature 2002, 416:740-743., [http://www.nature.com]

2. Harvard Medical School, [http://www.hms.harvard.edu/]

3. Dartmouth Medical School, [http://www.dartmouth.edu/dms/]

4. O'Toole GA: A resistance switch. Nature 2002, 416:695-696., [http://www.nature.com] 